\title{
The Law of Nations in German historia literaria and Encyclopaedias in the Eighteenth Century
}

\author{
Frank Grunert
}

\section{$1 \quad$ Introduction: Textbooks for Academic Teaching}

If one is interested in the law of nations as an academic subject, one clearly has to focus on lectures and textbooks dedicated to the subject. But from a historical point of view, it is worthwhile also to analyse the more general knowledge of the law of nations - that provided to non-specialists and especially to young academics before they started their specialist training. What did a beginning academic get to know about the law of nations? The propaedeutic lessons available provide interesting information regarding what the general academic public knew about the subject.

In the German context during the eighteenth century, historia literaria ('Geschichte der Gelehrsamkeit', 'history of learning') was the most prominent genre of general instruction in any subject of academic relevance. Its prominence is shown by the large number of textbooks which appeared throughout the whole of the century and the significant number of courses which were offered at all universities, academies and even at high schools. For more than a century, historia literaria was considered extremely successful, keeping the same general aim and changing only in the form of its practical realization. An authoritative definition of the purpose of historia literaria is given in Christoph August Heumann's Conspectus reipublicae literariae sive via ad historiam literariam, which appeared for the first time in 1718 and for the last time in a posthumous eighth edition in the 179os. Heumann provides that definition in the first paragraph: 'The history of learning is the history of letters [i.e. books] and authors, or the narration of the origin and progress of learning from the beginning up to our times.' ${ }^{1}$

1 Christoph August Heumann, Conspectus reipublicae literariae sive via ad historiam literariam iuventuti studiosae aperta, editio tertia (Hannover: apud Io. Jacobum Foersterum, 1733), 1: 'Historia literaria est Historia literarum et literatorum, sive Narratio de ortu et progressu studiorum literariorum ad nostram usque aetatem'. See: Sicco Lehmann-Brauns, 'Neukonturierung und methodologische Reflexion der Wissenschaftsgeschichte. Heumanns 
The original idea of historia literaria goes back to Francis Bacon. In Of the Proficience and Advancement of Learning (1605) Bacon suggested the establishment of a new historical discipline distinct from civil history and ecclesiastical history which had to represent all knowledge of the past - ideally without any limits. Bacon's objective was a sort of enormous repository of all knowledge from every period and every geographical area, with the purpose of giving constructive impulses to both scientific research and political governance. ${ }^{2}$ Since his concept had utopian dimensions, it is not surprising that its realization is also described in his New Atlantis. ${ }^{3}$ Although the German historians of learning and scholarship were fascinated by the idea of collecting every piece of former knowledge, they realized that a complete collection of knowledge was simply impossible. So while they adopted the idea, they reduced its scope and adapted it to propaedeutic purposes. That is, they decided to provide a focused and comprehensive survey of important scholarly information about all disciplines at any given time for the benefit of students in all disciplines. That comprised for example bibliographical and biographical information, outlines

Conspectus reipublicae literariae als Lehrbuch der aufgeklärten Historia literaria,' in Historia literaria. Neuordnung des Wissens im 17. Und 18. Jahrhundert, ed. Frank Grunert and Friedrich Vollhardt (Berlin: Akademie Verlag, 2007), 129-16o; Helmut Zedelmaier, 'Heumanns Conspectus Reipublicae Literariae. Besonderheit, Kontext, Grenzen,' in Christoph August Heumann (1684-1764). Gelehrte Praxis zwischen christlichem Humanismus und Aufklärung, ed. Martin Mulsow, Kasper Risbjerg Eskildsen and Helmut Zedelmaier (Stuttgart: Franz Steiner, 2017), 71-92. For more information on historia literaria in general, see Martin Gierl, 'Bestandsaufnahme im gelehrten Bereich. Zur Entwicklung der "Historia Literaria” im 18. Jahrhundert,' in Denkhorizonte und Handlungsspielräume. Festschrift für Rudolf Vierhaus zum 7o. Geburtstag (Göttingen: Wallstein, 1992), 53-80; Helmut Zedelmaier, “'Historia Literaria”. Über den epistemologischen Ort des gelehrten Wissens in der ersten Hälfte des 18. Jahrhunderts,' Das achtzehnte Jahrhundert, 22, 1 (1998): 11-21. Frank Grunert, Anette Syndikus, 'Historia literaria. Erschließung, Speicherung und Vermittlung von Wissen,' in Wissensspeicher der Frühen Neuzeit. Formen und Funktionen, ed. Frank Grunert and Anette Syndikus (Berlin: de Gruyter, 2015), 243-293; Hanspeter Marti, '§62. Litterärgeschichte (historia literaria),' in Grundriss der Geschichte der Philosophie, begr. von Friedrich Ueberweg. Die Philosophie des 18. Jahrhunderts, ed. Helmut Holzhey and Vilem Mudroch (Basel: Schwabe, 2014), vol. 5, 1425-1429. And last but not least the contributions in Frank Grunert and Friedrich Vollhardt (eds.), Historia literaria. Neuordnung des Wissens im 17. und 18. Jahrhundert (Berlin: Akademie Verlag, 2007).

2 Francis Bacon, Of the Proficience and Advancement of Learning, Divine and Humane (1605), in The Works of Francis Bacon, ed. James Spedding et al., vol. 3 (London: Longman, 1859).

3 Francis Bacon, The New Atlantis (1627), ibid., vol. 3. See Frank Grunert, "Viel Tausend und Millionen Bücher". Zur Bewältigung und zur Hervorbringung von Wissenspluralität in der frühneuzeitlichen "Historia literaria", in Pluralisierungen. Konzepte zur Erfassung der Frühen Neuzeit, ed. Jan-Dirk Müller, Wulff Österreicher and Friedrich Vollhardt (Berlin: de Gruyter, 2010), 192-194; Grunert and Syndikus, 'Historia literaria. Erschließung, Speicherung und Vermittlung von Wissen,' $253-255$. 
of the nature and development of disciplines, and at least some advice for learning and conducting scientific work. So, generally, German historia literaria became an important part of propaedeutic lessons to introduce students to the world of academic erudition. ${ }^{4}$

Despite its prominence historia literaria was - especially in the second half of the century - complemented by another historical genre, which pursued a similar aim. This was the encyclopaedic text, which likewise offered a first orientation in the scientific world, especially for beginning students and the general public. Encyclopaedias focused on each discipline by defining its nature and its function. They also recommended important authors and their books, but, unlike historia literaria, they did not try to present a more or less full history of the disciplines - they did not give a 'narratio de ortu et progressu disciplinarum' (Heumann). Instead they concentrated on a short sketch ('kurzer Begriff') and avoided long and sometimes complicated histories. These texts were organized as a course in all the academic disciplines, and accordingly they were generally called 'encyclopaedias', after the Greek term popularized during the Renaissance 'enkyklios paedeia', meaning the circle of learning about a certain subject with propaedeutic aims. The encyclopaedia as a repository of knowledge has its own rather long history, but the idea became more and more attractive in the second half of the eighteenth century, which may indicate a crisis for historia literaria. ${ }^{5}$ The assimilation of the detailed historical and bibliographical information of the latter seemed no longer feasible, at least not in the eyes of a part of the public. The purpose and the structure of the general historia literaria were nevertheless continued in specialized histories of individual disciplines. So the general knowledge of the law of nations that was provided to non-specialists at the beginning of their academic training during the eighteenth century is to be found in three particular historical genres: the general historia literaria, the specialized history of scholarship focused on one discipline, and the broader encyclopaedia.

In relation to the perception and the presentation of the law of nations, it is necessary to keep the following questions in mind: 1. To which discipline

4 Paul Nelles, 'Historia litteraria at Helmstedt: Books, professors and students in the early Enlightenment university', in Die Praktiken der Gelehrsamkeit in der Frühen Neuzeit, ed. Helmut Zedelmaier and Martin Mulsow (Tübingen: Niemeyer, 2001), 147-176; Anette Syndikus, 'Historia literaria als Propädeutikum an der Königsberger Universität des 18. Jahrhunderts,' in Die Universität Königsberg in der Frühen Neuzeit, ed. Hanspeter Marti and Manfred Komorowski (Köln, Wien, Weimar: Böhlau, 20o8), 379-422.

5 See Grunert, Syndikus, 'Historia literaria. Erschließung, Speicherung und Vermittlung von Wissen,' 289-293. 
was the law of nations said to belong? 2. How was the law of nations defined? 3. How were natural law and the law of nations said to relate to each other? 4. Which authors and which books were principally presented in discussions of the law of nations? It is important to note that the following sketch does not deal with the history of the law of nations itself: the aim is only to set out the ideas of a couple of representative authors who were significant in the history of learning for a certain period. The purpose is to find out what contemporaries learned about the law of nations when they studied the widely used textbooks on the history of learning and encyclopaedias.

2

\section{A Brief Sketch: the Law of Nations, Seventeenth to Eighteenth Century}

Before our questions can be answered, it is necessary to outline the discussion of the law of nations in the seventeenth and eighteenth centuries. If one surveys the whole debate, beginning inevitably with the highly influential categorical distinctions in Grotius's De jure belli ac pacis and ending most plausibly with the Primae lineae juris gentium Europaeum (1785), a general treatise on international law by the Göttingen law professor Georg Friedrich von Martens, one can get the impression that the core of the whole discussion was the relationship between natural law and the law of nations (jus gentium). Grotius made a distinction between the voluntary law of nations and natural law - as Francisco Suárez had done before - but the idea of a voluntary law of nations was rejected by Samuel Pufendorf, who asserted that only natural law can create obligations between states. As a consequence, the discussion went on between two more or less extreme positions: on the one hand, that of 'naturalists', such as Pufendorf and Samuel Cocceji, who relied on natural law and denied that a manmade law of nations can invoke more or less universal obligations; and on the other hand, that of thinkers such as Johann Jakob Moser and Georg Friedrich von Martens, who emphasized the manmade aspect of the law of nations along with an early positivist philosophy of international law, to use anachronistic terms. ${ }^{6}$

6 See Stephen C. Neff, Justice among Nations. A History of International Law (Cambridge, MA: Harvard University Press, 2014), esp. 155-201; Wilhelm Grewe, The Epochs of International Law, transl. and revised by Michael Byers (Berlin: de Gruyter, 2000), esp. 348-360; Oliver Diggelmann, 'The Periodization of the History of International Law,' in The Oxford Handbook of the History of International Law, ed. Bardo Fassbender and Anne Peters (Oxford: Oxford University Press, 2012), 997-1011; Karl-Heinz Ziegler, Völkerrechtsgeschichte, and 
Since Pufendorf had set the tone ${ }^{7}$ it is hardly surprising that his highly influential follower Christian Thomasius had no concern at all with the law of nations. Thomasius of course knew everything that Hugo Grotius had written on this topic, but clearly he had no interest in it. In his eyes, the law of nations is just a part of natural law, which deals with only two issues, namely duties towards legatees - 'De officiis erga legatos' - and duties towards deceased persons - 'De officio erga mortuos': 'There remains the society of nations, in which as we already said above no new purpose or new precepts are to be expected, only the application of the general precepts set out in the second book to two of the more important parts of the law of nations, those concerning legations and the right of burial:.8 But while Thomasius stuck to this as far as the duties to diplomats are concerned and explicitly denied that they formed part of a voluntary law of nations, he went on to argue that the duties towards deceased persons are not a subject of natural law but that they do not contradict it. One may wonder why he discussed them in the context of the law of nations at all, but it confirms the impression of his entire lack of interest in the law of nations in his first book on natural law, an impression that is reinforced in his second major work in the field, the Fundamenta juris naturae et gentium (1705). ${ }^{9}$

However, during the lifetime of Thomasius, Adam Friedrich Glafey returned to Grotius's distinction between natural law and jus gentium voluntarium. He seemed to follow Thomasius and other natural lawyers when he stated that the law of nations is nothing but an 'applicatio regularum Juris naturae ad statum gentium, ${ }^{10}$ Nevertheless, he emphasized the already existing concept of jus gentium voluntarium ('willkührliches Völker-Recht'), which he defined

ed. (München: Beck, 2007); Tilmann Altwicker, Francis Cheneval, Oliver Diggelmann (eds.), Völkerrechtsphilosophie der Frühaufklärung (Tübingen: Mohr Siebeck, 2015).

7 See for a more detailed discussion of Pufendorf's concept of the law of nations: Michael Seidler, 'Der Begriff des Völkerrechts bei Samuel Pufendorf', in Völkerrechtsphilosophie, ed. Altwicker, Cheneval and Diggelmann, 61-78.

8 Christian Thomasius, Institutes of Divine Jurisprudence with Selections from Foundations of the Law of Nature and Nations, ed., transl. and with an introduction by Thomas Ahnert (Indianapolis, IN: Liberty Fund, 2011), 544. English translation of Institutiones jurisprudentiae divinae (Frankfurt and Leipzig: M.G. Weidmann, 1688).

9 Christian Thomasius, Fundamenta juris naturae et gentium (Halle: Salfeld, 1705). For the English translation see note 8 .

10 Adam Friedrich Glafey, Vernunfft- und Völcker-Recht (Frankfurt and Leipzig: Christoph Riegel, 1723), 231. For Glafey's ideas of the law of nations, see Frank-Steffen Schmidt, Praktisches Naturrecht zwischen Thomasius und Wolff: Der Völkerrechtler Adam Friedrich Glafey (1692-1753) (Baden-Baden: Nomos, 2007), esp. 199ff. 
as 'customs $[\ldots]$, which were transformed into rights through common practice among different nations and admitted to be obligatory law among them.'11 Glafey explicitly contrasted this idea with the position of Christian Thomasius and thus demonstrated a certain interest in the theoretical independence of the law of nations.

A similar interest was shown by Christian Wolff through the publication of his Jus gentium methodo scientifica pertractatum (1749) separately from his eight-volume Jus naturae (1740-1749). Based on the Grotian dualistic conception, Wolff announced a careful distinction of the 'Natural Law of Nations [...] from that which is voluntary, stipulative and customary'.12 He opened his Jus gentium with the following definition: 'By the Law of Nations we understand the science of that law which nations or peoples use in their relations with each other and the obligations corresponding thereto.'.13 Wolff admitted that the Jus gentium necessarium consists in natural law as applied to nations in general, ${ }^{14}$ but he introduced a more comprehensive definition of the law of nations, which encompasses all juridical relations between nations without regard to their sources. The complete emancipation of the law of nations from any kind of natural law was accomplished in the works of Johann Jakob Moser and Georg Friedrich von Martens. They were interested in practical agreements as guidelines for politics and even explicitly denied 'the existence of a general international law'. ${ }^{15}$ It is therefore not surprising that especially von Martens 'was regarded, with at least some reason, as an important progenitor of the positivist philosophy of international law'.16

11 Glafey, Vernunff- und Völcker-Recht, 195: ‘[D]iejenigen Gebräuche [...], welche bey verschiedenen Völkern durch langen Brauch zu Rechte gediehen, und sie unter sich als ein verbindliches Recht gelten lassen'.

12 Christian Wolff, The Law of Nations treated according the Scientific Method, transl. by Joseph H. Drake, ed. and with an introduction by Thomas Ahnert (Carmel, IN: Liberty Fund, 2017), 1.

13 Wolff, The Law of Nations, 12. Christian Wolff, Jus Gentium Methodo Scientifica Pertractatum (Halle: Renger, 1749), in Gesammelte Werke, Abt. 2, vol. 25 (Hildesheim, Zürich, New York: Olms, 1972), 1: 'Per Jus Gentium intelligimus scientiam juris, quo Gentes, sive populi inter se utuntur \& obligationum eidem respondentium'. On Wolff see Knud Haakonssen, 'Christian Wolff (1679-1754),' in The Oxford Handbook of the History of International Law, ed. Fassbender, Peters, 1106-1109.

14 Wolff, The Law of Nations, 14: 'We call that the necessary law of nations which consists in the law of nature applied to nations'.

15 Neff, Justice among Nations, 194, see also 199.

16 Ibid., 200. 


\section{Neglect: the Law of Nations in the Early General} Compendia of historia literaria

Turning to the textbooks in historia literaria, we clearly find all steps in the development sketched above. Especially in the first half of the century, one can get the impression that there is nearly no interest in dealing with the law of nations as a special topic. It is surprising that the historians of learning in the early eighteenth century, despite their programmatic aims and explicit intentions, sometimes completely ignore the law of nations. We find detailed remarks on natural law in volume 3 of the famous Kurtze Anleitung zur Historie der Gelahrheit $(1718)^{17}$ by Gottlieb Stolle, a student of Christian Thomasius, but not a single word on the law of nations. Neither does the later and otherwise detailed Anleitung zur Historie der juristischen Gelahrheit $(1745)^{18}$ by the same author deal with the law of nations. Apparently, Stolle still did not consider it a topic in jurisprudence. The same lack of interest can be observed in Heumann's Conspectus. He there presents a very brief 'historia jurisprudentiae naturalis', but the term 'jus gentium' appears, without any further explanation, only in the context of some remarks about Samuel Pufendorf's natural law. ${ }^{19}$

Nicolaus Hieronymus Gundling - also a former student of Christian Thomasius - treats the history of natural law in his programme announcing a Collegium uber die Historiam litterariam (1713). No more than a list of items to be highlighted in his lecture, number 106 in the programme explicitly asks whether jus gentium should be treated separately from natural law - 'ob das Ius Gentium besonders zu tractiren' - and he adds that in this context he will make some remarks on Johann Wolfgang Textor's Synopsis Juris Gentium. ${ }^{20}$ One may expect that he would present some definition of the law of nations, but the programmatic text does not allow us to tell. In his treatise on natural law Gundling rejects the necessity of treating the law of nations, because he explicitly denies it a separate identity; it is nothing but the application of natural law to nations. ${ }^{21}$ We find the same position in the Versuch zu einer Historie

\footnotetext{
17 Gottlieb Stolle, Kurtze Anleitung zur Historie der Gelahrheit (Halle: Neue Buchhandlung, 1718).

18 Gottlieb Stolle, Anleitung zur Historie der juristischen Gelahrheit (Jena: Johann Meyers seel. Erben, 1745).

19 Heumann, Conspectus, 245.

20 Nicolaus Hieronymus Gundling, Collegium uber die Historiam litterariam (Halle, [1713]), 35. Johann Wolfgang Textor, Synopsis juris gentium (Basel: Rüdinger, 168o).

21 Nicolaus Hieronymus Gundling, Jus naturae ac gentium, 3rd ed. (Halle: Renger 1736), $20-21$.
} 
der Gelehrheit (1728) by Martin Schmeitzel, a historian and a former student of Gundling. He, too, explains that he treats jus naturae and jus gentium together because the latter is only jus naturae applied to the nature and the negotiations of nations. ${ }^{22}$ His further treatment of the law of nations is as meagre as that in the large Abriß einer allgemeinen Historie der Gelehrsamkeit (1752-1754), in whose three volumes Johann Andreas Fabricius found room for only one sentence on the subject: 'when natural law is applied to the state of nations it is called the law of nations which deals with the rights and duties of nations and countries towards each other.23 Fabricius, who was a famous historian of learning, classified natural law and hence the law of nations as part of philosophy. In other words, the works of Glafey and Wolff on the law of nations did not lead Fabricius to include any further details on that law.

\section{Philosophy vs. Law: the Law of Nations in Later Compendia of historia literaria and in Encyclopaedias}

However, as times changed so did theories. In textbooks on the history of learning from the second half of the eighteenth century, the law of nations was dealt with in a far more elaborate way. The change is still more obvious if one includes the already mentioned encyclopaedias and the specialized compendia of historia literaria, texts such as Johann Georg Sulzer's Kurzer Begriff aller Wissenschaften ${ }^{24}$ (1759), Christian Heinrich Schmid's Abriß der Gelehrsamkeit ${ }^{25}$ (1783), Johann Joachim Eschenburg's Lehrbuch der Wissenschaftskunde 26 (1792), Johann Stephan Pütter's Neuer Versuch einer Juristischen Encyclopädie und Methodologie ${ }^{27}$ (1767) or Dietrich Heinrich Ludwig von

22 Martin Schmeitzel, Versuch zu einer Historie der Gelehrheit (Jena: Fickelscherr, 1728), 552.

23 Johann Andreas Fabricius, Abriß einer allgemeinen Historie der Gelehrsamkeit, vol. 1 (Leipzig: Weidmann, 1752), 402: '[W]enn dieses Recht der Natur auf den Stand der Völker angewendet wird, so heißt es das Völkerrecht und ist sodann die Wissenschaft der Rechte und Pflichten der Völker und Staaten gegeneinander'.

24 Johann Georg Sulzer, Kurzer Begriff aller Wissenschaften und andern Theile der Gelehrsamkeit, worin jeder nach seinem Innhalt, Nuzen und Vollkommenheit kürzlich beschrieben wird, 4th ed. (Frankfurt and Leipzig: [s.n.],1774).

25 Christian Heinrich Schmid, Abriß der Gelehrsamkeit für encyklopädische Vorlesungen (Berlin: Himburg, 1783).

26 Johann Joachim Eschenburg, Lehrbuch der Wissenschaftskunde ein Grundriß encyklopädischer Vorlesungen (Berlin, Stettin: Nicolai, 1792).

27 Johann Stephan Pütter, Neuer Versuch einer Juristischen Encyclopädie und Methodologie nebst etlichen Zugaben (Göttingen: Vandenhoeck, 1767). 
Ompteda's extensive Litteratur des gesammten sowohl natürlichen als positiven Völkerrechts (1785). ${ }^{28}$

There can be no doubt that the Wolffian concept of the law of nations caused this change. Although all these authors acknowledge the close connection between the law of nations and natural law, they treat the law of nations as in some sense a sui generis discipline and deal with it in special chapters or paragraphs, separate from natural law. Beginning with Sulzer, we see that for him the law of nations was still a part of natural law and therefore belonged to philosophy, but he nevertheless treated the law of nations in a special paragraph directly after his remarks on natural law. Sulzer defined jus gentium in the traditional way: 'If one considers different independent civil societies as individual persons and if one applies natural law to these persons, then one gets the law of nations. This law deals with the duties of free states towards each other and analyses their rights concerning peace and war, alliances, pacts and negotiations.29 In his chapter on jurisprudence he mentions natural law again and considers it to be the theoretical basis for law as a whole, but in this explicitly juridical context he does not refer to the law of nations. Since Sulzer was a philosopher and not a lawyer, one should perhaps not expect him to focus on juridical questions, but nevertheless one gets the impression that the law of nations is still not important enough to be treated in a more detailed way, despite the development of the subject into a more and more self-reliant discipline.

This development marks the difference between Sulzer and the later authors. Thus towards the end of our period, Johann Georg Meusel's Leitfaden zur Geschichte der Gelehrsamkeit (180o) emphasizes that 'praktisches Völkerrecht' is a new part of jurisprudence and refers to Vattel, Mably, Martens, Günther and von Römer as eminent authors in this field. ${ }^{30}$ Eschenburg's

28 Dietrich Heinrich Ludwig von Ompteda, Litteratur des gesammten sowohl natürlichen als positiven Völkerrechts. Erster Theil. Nebst vorangestellter Abhandlung von dem Umfange des gesammten sowohl natürlichen als auch positiven Völkerrechts, und Ankündigung eines zu bearbeitenden vollständigen Systems desselben, part 2 (Regenburg: Montag, 1785).

29 Sulzer, Kurzer Begriff aller Wissenschaften, 173-174: 'Wenn man verschiedene unabhängliche bürgerliche Gesellschaften als einzelne Personen betrachtet, und das Recht der Natur auf diese Personen anwendet, so entstehet daher das Völkerrecht. Dieses betrachtet demnach die Pflichten, welche ein freyer Staat gegen andere zu beobachten hat, und untersucht das Recht der freyen Staaten in Ansehung des Krieges und Friedens, der Bündnisse, Verträge und Handlungen'.

30 Johann Georg Meusel, Leitfaden zur Geschichte der Gelehrsamkeit (Leipzig: Fleischer, 180o), 1310: 'Ein neuer Zweig ist das praktische Völkerrecht, in welchem vor dem 18. Jahrhundert noch wenig gearbeitet war'. 
Lehrbuch der Wissenschaftskunde (1792), which was supposed to be a Grundriß encyclopädischer Vorlesungen, is an interesting case insofar as he discusses the law of nations twice: in philosophy and in jurisprudence. As a rather traditional philosopher he suggests that the law of nations is closely connected to natural law and treats the nation as a moral person, but he also distinguishes between the law of nations in general and the positive law of nations: the former 'is based on the general relationships between peoples; [the latter] contains the mutual obligations established between several peoples through custom and contracts.'. ${ }^{31}$ Wolff's Jus gentium and Emer de Vattel's Le droit des gens are recommended for further reading. When Eschenburg treats the law of nations in his chapter on jurisprudence, he simply repeats his remarks from the earlier chapter on philosophy without adding details from the perspective of jurisprudence. The way in which he treats the law of nations twice is indicative of the tendency for the law of nations to make it independent from philosophy.

However, an interesting detail may correct this impression. In the chapter on jurisprudence Eschenburg emphasizes that the natural law of nations ('natürliches Völkerrecht') is the basis of the positive law of nations, 'which fairly deduces its judgements and principles from this source, and which has to be led back to it, in spite of all modifications caused by the requirements of the people. ${ }^{32} \mathrm{He}$ also states in the chapter on philosophy that the obligation of the general law of nations is much stronger than the vis obligandi of the positive law, 'because those are founded on the rights and claims of reason itself, while these in contrast are based on particular temporary agreements and agreed conditions'. ${ }^{33}$ These remarks strengthen the role of philosophy and run counter to the impression mentioned above. Eschenburg seems to try to defend the philosophical status of the law of nations against the already established claim by lawyers that the positive law of nations belongs to juridical practice. In other words, a philosopher is defending his turf against the professional claims by jurists.

31 Eschenburg, Lehrbuch der Wissenschaftskunde, 109: 'Jenes beruht auf den allgemeinen Verhältnissen eines Volks gegen andre; dieses enthält die zwischen mehrern Völkern durch Herkommen und Verträge festgesetzten gegenseitigen Verbindlichkeiten des Verhaltens'.

32 Ibid., 262: '[W]elches seine Entscheidungen und Grundsätze billig aus dieser Quelle herleiten, und, bei aller ihrer nach den Bedürfnissen jedes Volks abgeänderten Anwendung, doch zuletzt auf dieselbe zurückführen muß'.

33 Ibid., 109: '[W] eil jenes die Rechte und Ansprüche der Vernunft, dieses hingegen gewisse vorläufige Einwilligungen und gemachte Bedingungen zum Grunde hat'. 


\section{Effects of Specialization: the Law of Nations in Juridical} Encyclopaedias and the Example of a Specialized historia literaria

The emphasis on the juridical function of the positive law of nations is characteristic of the Göttingen school of law. Johann Stephan Pütter - one of the most famous exponents of this school - wrote his Neuer Versuch einer juristischen Encyclopädie und Methodologie for law students, not for a general academic readership. The law of nations plays a significant role in Pütters's Encyclopädie, insofar as he mentions it at all levels of the work. In his chapter on legal theory he deals with the law of nations together with natural law; in the chapter on positive law, he treats the practical law of nations, especially with respect to the German Empire; and he also speaks about the law of nations in his methodological remarks at the end of the book. In a now familiar way, Pütter distinguishes between the general law of nations ('allgemeines Völkerrecht'), which only applies the principles of natural law to nations, ${ }^{34}$ and the positive law of nations, which is based on contracts on the one hand and customs or tacit consent on the other:

So entire nations do not have other sources of obligation than contracts. Thus there is in fact no other law of nations than the universal one which is a part of the law of nature $(\S 19)$. But since obliging customs can be created by tacit consent and since several nations, which are related to each other by sharing the same historical level of civilization, the same soil, the same religion and things like that, agree upon certain principles by contracts and customs, another voluntary (positive) law of nations can be conceived, which undoubtedly exists among the European states today and which already existed in former times. ${ }^{35}$

34 Pütter, Neuer Versuch einer juristischen Encyclopädie und Methodologie, 10-11.

35 Ibid., 13-14: 'Ganze Völker haben daher unter einander keine andere Quelle von dieser Art Verbindlichkeiten, als die sie sich selbst mit Verträgen aufladen. Folglich gibt es eigentlich kein ander Völkerrecht, als das allgemeine, so einen Theil des Rechts der Natur ausmacht (§19). Jedoch sofern auch aus stillschweigender Einwilligung verbindliche Gebräuche entstehen können, und sofern mehrere Völker, die einerlei Welt-Alter, einerley Theil des Erdbodens, einerley Religion und was dergleichen mehr ist, in nähere Verbindung setzt, sich durch Gebräuche und Verträge auf gewisse Grundsätze vereinbaren, und insonderheit manche sonst dem allgemeinen Völkerrechte nach unbestimmte Dinge näher zu bestimmen; so läßt sich noch ein weiteres willkührliches (positives) Völkerrecht denken, dergleichen heutiges Tages unter den Europäischen Staaten unleugbar ist, und in vorigen Zeiten eben so wenig ohne Beyspiel gewesen'. 
This positive law of nations plays multiple roles, especially in Germany. It is applied to the relations between the German Empire as a whole with foreign countries, but it is also applied to the relations of the individual territorial states of the Empire with foreign countries, to the relations of the individual German territorial states with each other, and finally to relations between the individual territorial states and the Empire as a whole. So Pütter is right when he states that a German lawyer has a lot of opportunities to work in the field of the law of nations. For this reason, he recommends his students to study history, especially the modern conflicts between European nations since the Peace of Westphalia, and all parts of the practical law of nations and 'statistics' ('Staatenkunde', theory of the state). ${ }^{36}$ So there is no doubt about the juridical importance of the positive law of nations and, hence, of the necessity to present it extensively in the juridical encyclopaedia. As we have seen, Pütter acknowledges the logical priority of natural law as the basis of all general concepts of law, and he certainly stresses that a lawyer is especially useful ('desto brauchbarer') when he combines a wide range of knowledge of positive law (including the positive law of nations) and case law with the ability to base this knowledge on general terms and concepts. So the study of natural law and the study of positive law (including the positive law of nations) should be linked. To this end, Pütter recommends that natural law should be studied not only at the beginning but also at the end of legal education, 'since especially general constitutional law and the law of nations deserve to be reconsidered in a way that is not possible on the first entry into the study of law'. ${ }^{37}$ In spite of its logical priority, it is clear that aspects of natural law - the general constitutional law and the general law of nations - should be re-interpreted, maybe extended or even modified in the light of positive law in general and of the positive law of nations in particular. So the emancipation of the law of nations has reached a much higher level.

The final step was taken by a student and friend of Pütter, Dietrich Heinrich Ludwig von Ompteda, significantly a lawyer, diplomat, and politician, not an academic. ${ }^{38}$ In his Litteratur des gesammten sowohl natürlichen als positiven Völkerrechts (1785) we find everything we missed in all the other compendia. Ompteda delivered a careful 'historia litteraria seu litteratura juris gentium'39

36 Ibid., 102.

37 Ibid., 67: '[D]a insonderheit auch das allgemeine Staats- und Völker-Recht wohl verdiente, alsdenn noch mit andern Augen angesehen werden, als es beym ersten Eintritt in die Rechtswissenschaft geschehen kann'.

38 The title page of his book mentions Ompteda's functions: 'Königl. Grosbrit. Churfürstl. Braunschw. Lüneb. Comitial-Gesandter bey der Reichsversammlung zu Regensburg und bevollmächtigter Minister am Churpfälz. Hofe zu München'. Ompteda, Litteratur des gesammten sowohl natürlichen als positiven Völkerrechts, 91. 
of no less than 672 pages, in which topics were extensively differentiated - the detailed table of contents alone takes up 21 pages. The book met a desideratum of his time. When Ompteda began his study of international law, he was amazed by the quantity of bibliographical material and the complete lack of guidance through the wide-ranging scholarship on the law of nations. Other scholars had lamented that there was no compendium to this literature, although the law of nations was already an independent discipline separate from natural law. ${ }^{40}$ Ompteda considered his book to be a counterpart to Pütter's Litteratur des teutschen Staatsrechts. Like Pütter's, it is divided into two parts, 'history of the discipline and bibliographical guidance'41 - and it does in fact provide a highly systematic and annotated bibliography of the whole of the relevant literature on the law of nations. Ompteda's work is not a compendium of historia literaria intending to offer an orientation to the world of academic knowledge to new students. It is, rather, a general reference work, written for experts by an expert who was a lawyer and a politician at the same time.

German histories of learning seem to reflect fairly precisely the development of the general discussion of the law of nations in Germany. Initially, historians of scholarship were not interested in presenting the theoretical aspects of or bibliographical material on the law of nations, thus reflecting the distance of early natural lawyers to the subject - although the historia literaria juris gentium of Ompteda does provide evidence that the earlier discussion of the law of nations was in fact more lively than one might have expected. In all the compendia consulted for the present survey, discussions of natural law dominate. It played a significant role in normative political thought and - perhaps even more - in moral theory, so it is not surprising that those historians of learning and those authors of encyclopaedias who had moral concerns ${ }^{42}$ focused on natural law, especially since this focus was supported by the political circumstances in Germany, with its composite constitutional structure. The situation changed when the works of Glafey, Wolff and Vattel appeared - the discussion of international law became more elaborate and it was given a theoretical and practical basis.

$40 \quad$ Ibid., 'Vorrede,' n.p.

41 Ibid., 93: 'Geschichte der Wissenschaft und Bücherkunde'.

42 See Frank Grunert, 'Von "guten” Büchern. Zum moralischen Anspruch der Gelehrsamkeitsgeschichte,' in Historia literaria, ed. Grunert and Vollhardt, 65-88. 
The differentiation and specialization of the law of nations was reflected in historia literaria, which was a medium for scholarly developments, and when the law of nations became more important as a subject in legal studies, specialized propaedeutic compendia began to include more information on this field. The historia literaria juris gentium by Ompteda gives a wide-ranging overview of all aspects of the law of nations, from the earliest times to his own. Even though it was not by any means fully specialized, it did facilitate even more differentiation. This development may be contrasted with the state of the generalist histories of learning, in which the treatment of the law of nations remained quite poor. These historians of scholarship - both before and after Friedrich Schiller's Briefe zur ästhetischen Erziehung des Menschen - pursued a more holistic ideal of explicit philosophical 'Bildung', and that entailed an aversion to specialization and a neglect of, for example, the emergence of the law of nations as a separate discipline, even when they were well aware of this.

\section{Bibliography}

Altwicker, Tilmann, Cheneval, Francis and Diggelmann, Oliver (eds.), Völkerrechtsphilosophie der Frühaufklärung (Tübingen: Mohr Siebeck, 2015).

Bacon, Francis, The Works of Francis Bacon, ed. James Spedding et al., vol. 3 (London: Longman, 1859).

Diggelmann, Oliver, 'The Periodization of the History of International Law, in The Oxford Handbook of the History of International Law, ed. Bardo Fassbender and Anne Peters (Oxford: Oxford University Press, 2012), 997-1011.

Eschenburg, Johann Joachim, Lehrbuch der Wissenschaftskunde. Ein Grundriß encyklopädischer Vorlesungen (Berlin and Stettin: Nicolai, 1792).

Fabricius, Johann Andreas, Abriß einer allgemeinen Historie der Gelehrsamkeit, vol. 1 (Leipzig: Weidmann, 1752).

Gierl, Martin, 'Bestandsaufnahme im gelehrten Bereich. Zur Entwicklung der "Historia Literaria" im 18. Jahrhundert,' in Denkhorizonte und Handlungsspielräume. Festschrift für Rudolf Vierhaus zum 7o. Geburtstag (Göttingen: Wallstein, 1992), 53-80.

Glafey, Adam Friedrich, Vernunfft- und Völcker-Recht (Frankfurt and Leipzig: Christoph Riegel, 1723).

Grewe, Wilhelm, The Epochs of International Law, transl. and revised by Michael Byers (Berlin: de Gruyter, 200o).

Grunert, Frank and Vollhardt, Friedrich (eds.), Historia literaria. Neuordnung des Wissens im 17. und 18. Jahrhundert (Berlin: Akademie Verlag, 2007).

Grunert, Frank, "Viel Tausend und Millionen Bücher". Zur Bewältigung und zur Hervorbringung von Wissenspluralität in der frühneuzeitlichen "Historia literaria", 
in Pluralisierungen. Konzepte zur Erfassung der Frühen Neuzeit, ed. Jan-Dirk Müller, Wulff Österreicher and Friedrich Vollhardt (Berlin: de Gruyter, 2010), 191-2O2.

Grunert, Frank and Syndikus, Anette, 'Historia literaria. Erschließung, Speicherung und Vermittlung von Wissen,' in Wissensspeicher der Frühen Neuzeit. Formen und Funktionen, ed. Frank Grunert and Anette Syndikus (Berlin: de Gruyter, 2015), 243-293.

Gundling, Nicolaus Hieronymus, Collegium uber die Historiam litterariam (Halle, [1713]).

Gundling, Nicolaus Hieronymus, Jus naturae ac gentium, 3rd ed. (Halle: Renger 1736).

Heumann, Christoph August, Conspectus reipublicae literariae sive via ad historiam literariam iuventuti studiosae aperta, editio tertia (Hannover: apud Io. Jacobum Foersterum, 1733).

Lehmann-Brauns, Sicco, 'Neukonturierung und methodologische Reflexion der Wissenschaftsgeschichte. Heumanns Conspectus reipublicae literariae als Lehrbuch der aufgeklärten Historia literaria,' in Historia literaria. Neuordnung des Wissens im 17. und 18. Jahrhundert, ed. Frank Grunert and Friedrich Vollhardt (Berlin: Akademie Verlag, 2007) 129-16o.

Marti, Hanspeter, '§ 62. Litterärgeschichte (historia literaria),' in Helmut Holzhey, Vilem Mudroch (eds.): Grundriss der Geschichte der Philosophie, begr. von Friedrich Ueberweg. Die Philosophie des 18. Jahrhunderts, vol. 5, ed. Helmut Holzhey and Vilem Mudroch (Basel: Schwabe, 2014), 1425-1429.

Meusel, Johann Georg, Leitfaden zur Geschichte der Gelehrsamkeit (Leipzig: Fleischer, 180o).

Neff, Stephen C., Justice among Nations. A History of International Law (Cambridge, MA: Harvard University Press, 2014).

Nelles, Paul, 'Historia litteraria at Helmstedt: Books, professors and students in the early Enlightenment university,' in Die Praktiken der Gelehrsamkeit in der Frühen Neuzeit, ed. Helmut Zedelmaier and Martin Mulsow (Tübingen: Niemeyer, 2001), 147-176.

Ompteda, Dietrich Heinrich Ludwig von, Litteratur des gesammten sowohl natürlichen als positiven Völkerrechts. Erster Theil. Nebst vorangestellter Abhandlung von dem Umfange des gesammten sowohl natürlichen als auch positiven Völkerrechts, und Ankündigung eines zu bearbeitenden vollständigen Systems desselben, part 2 (Regensburg: Montag, 1785).

Pütter, Johann Stephan, Neuer Versuch einer Juristischen Encyclopädie und Methodologie nebst etlichen Zugaben (Göttingen: Vandenhoeck, 1767).

Schmeitzel, Martin, Versuch zu einer Historie der Gelehrheit (Jena: Fickelscherr, 1728).

Schmid, Christian Heinrich, Abriß der Gelehrsamkeit für encyklopädische Vorlesungen (Berlin: Himburg, 1783).

Schmidt, Frank-Steffen, Praktisches Naturrecht zwischen Thomasius und Wolff: Der Völkerrechtler Adam Friedrich Glafey (1692-1753) (Baden-Baden: Nomos, 2007). 
Seidler, Michael, 'Der Begriff des Völkerrechts bei Samuel Pufendorf,' in Völkerrechtsphilosophie der Frühaufklärung, ed. T. Altwicker, F. Cheneval and O. Diggelmann (Tübingen: Mohr Siebeck, 2015), 61-78.

Stolle, Gottlieb, Kurtze Anleitung zur Historie der Gelahrheit (Halle: Neue Buchhandlung, 1718).

Stolle, Gottlieb, Anleitung zur Historie der juristischen Gelahrheit (Jena: Johann Meyers seel. Erben, 1745).

Sulzer, Johann Georg, Kurzer Begriff aller Wissenschaften und andern Theile der Gelehrsamkeit, worin jeder nach seinem Innhalt, Nuzen und Vollkommenheit kürzlich beschrieben wird, 4th ed. (Frankfurt and Leipzig: [s.n.],1774).

Syndikus, Anette, 'Historia literaria als Propädeutikum an der Königsberger Universität des 18. Jahrhunderts', in Die Universität Königsberg in der Frühen Neuzeit, ed. Hanspeter Marti, Manfred Komorowski (Köln, Wien, Weimar: Böhlau, 2oo8), 379-422.

Textor, Johann Wolfgang, Synopsis juris gentium (Basel: Rüdinger, 168o).

Thomasius, Christian, Institutiones jurisprudentiae divinae (Frankfurt and Leipzig: M.G. Weidmann, 1688).

Thomasius, Christian, Fundamenta juris naturae et gentium (Halle: Salfeld, 1705).

Thomasius, Christian, Institutes of Divine Jurisprudence with Selections from Foundations of the Law of Nature and Nations, ed., transl. and with an Introduction by Thomas Ahnert (Indianapolis, IN: Liberty Fund, 2011).

Wolff, Christian, Jus Gentium Methodo Scientifica Pertractatum (Halle: Renger, 1749), in Gesammelte Werke, Abt. 2, vol. 25 (Hildesheim, Zürich, New York: Olms, 1972).

Wolff, Christian, The Law of Nations treated according the Scientific Method, transl. Joseph H. Drake, ed. and with an Introduction by Thomas Ahnert (Carmel, IN: Liberty Fund, 2017).

Zedelmaier, Helmut, “Historia Literaria”. Über den epistemologischen Ort des gelehrten Wissens in der ersten Hälfte des 18. Jahrhunderts,' Das achtzehnte Jahrhundert 22, 1 (1998): 11-21.

Zedelmaier, Helmut, 'Heumanns Conspectus Reipublicae Literariae. Besonderheit, Kontext, Grenzen,' in Christoph August Heumann (1684-1764). Gelehrte Praxis zwischen christlichem Humanismus und Aufklärung, ed. Martin Mulsow, Kasper Risbjerg Eskildsen and Helmut Zedelmaier (Stuttgart: Franz Steiner, 2017), 71-92.

Ziegler, Karl-Heinz, Völkerrechtsgeschichte, 2nd ed. (München: Beck, 2007). 